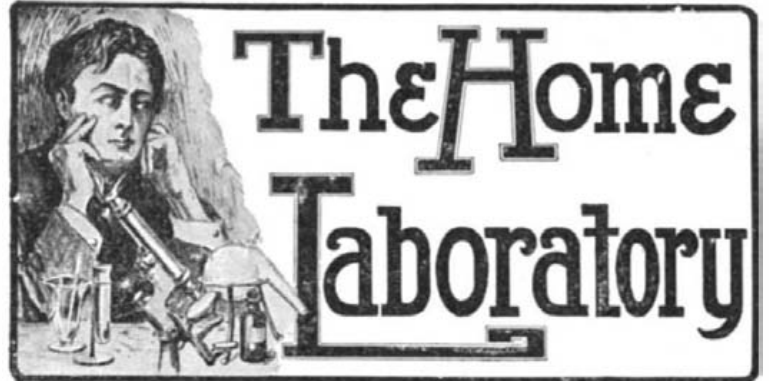

A ROUGH AND READY GALVANIC BATTERY. BY $\triangle$. J. JARMAN.

The best battery for experimental work in the workshop or laboratory is one of the rough-and-ready typ that will give a moderate current of electricity of say three or four amperes with an electromotive force of 1.5 to 3 volts. Such a battery is suited for the exciting of a powerful electromagnet, for magnetizing purposes, operating an induction coil, and for electro silver plating, electro brassing, or electro coppering either by the hot or cold process, and for electro gild ing. The .following description will enable anyone who can handle woodworking tools to construct such a battery consisting of two cells, capable of being coupled so as to give the current of one large cell or in series so as to yield the current of one cell and the electromotive force of two. This latter plan is the one best suited for coppering, brassing or electro nickeling. This type of battery has been used, and is still used by the writer for all the purposes mentioned, for over five years, so it has been put well to the test of experience.

The wood used in making the battery must be thor oughly well seasoned. An old board that has bee kept years in an office or a loft will prove to be Just the thing required. The board should be 1 inch thick. Cut a strip 5 feet. long and 8 inches wide. Plane this smooth all over and then cut three pieces $131 / 2$ inches long, and three pieces $51 / 2$ inches long. The latter will form the ends and central division of the battery. The side pieces inust be grooved so as to re ceive these pieces with a very nice fitting joint a shown in Fig. 1. The bottom piece must be made as shown in Fig. 2, with two pieces of wood cut exactly 5 inches square, this size being the inside measure ment of each cell. These squares must be held in place by means of screws that are inserted from the underside of the bottom board and penetrate to within $1 / 4$ inch of the outer surface of the squares. They should also be coated with a thick shellac varnish (not glue) before being fastened in place. The grooves in the side pieces and the ends of the division piece must also be well coated with thick shellac varnish, after which the pieces should be driven tightly together and held by nails or screws. Nails driven diagonally make the best job because they will draw the woodwork together more firmly than screws, and resist direct strain better. The object of using shellac is to insure a perfect acid-proof joint, and the 5 inch square pieces where pressed into position form bottom so firm that no acid liquid will penetrate.

When the battery has been put together it must be lined on the inside with a coating of burning-hot pitch. Use an old saucepan to melt the pitch in. Pour some into one of the cells and tilt the battery first one side then another until all four sides have been submitted to the hot pitch. Pour the pitch back into the saucepan, take a strip of square or flat iron, make one end red hot, and press this well into the corners and around the joints at the bottom, so as to secure

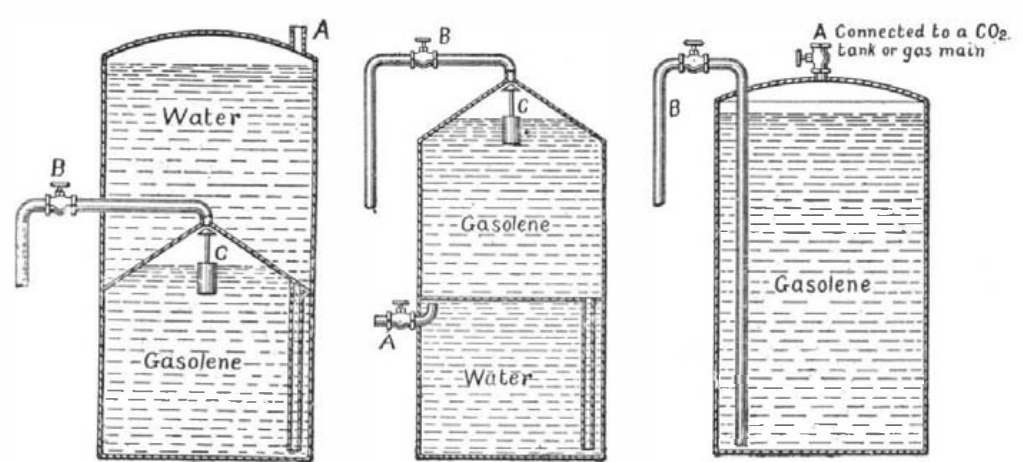

SIMPLE METHODS OF MAKING GASOLINE TANKS SAFE.

brass battery clamps to these with a strip of sheet copper folded over the top of the carbon block. This is an important item. Its use will protect the brass clamp from being corroded by the acids. The zinc cylinders can be purchased with a copper strip and binding screw attached. The zinc cylinders must be amalgamated by dipping them into sulphuric acid 1 part, water 8 parts, and then rubbing all over inside and outside with quicksilver. Place these zincs in the wooden vessel. Make up a mixture of sulphuric acid 1 pint, water 8 pints in a stoneware pitcher, and llow it to become cold. In another vessel make a mix. ture of water 4 pints, bichromate of sodium or potas-
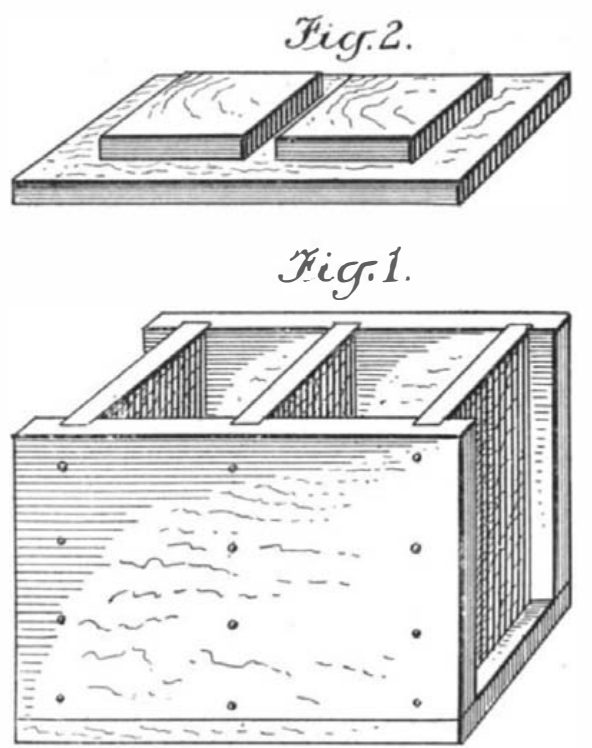

A ROL TH AND READY GALVANIC BATTERY.

sium 12 ounces, sulphuric acid half a pint. Allow this also to become cold. The battery is now charged by pouring the bichron ate mixture into the porous pots, around the carbon blocks, and then pouring the sulphuric acid mixture into the outside space around the zinc cylinders. The battery is now ready for any purpose required and will keep in good action for about six hours continuously. When not in use the zinc cylinders must be removed and placed into a stoneware crock filled with water, and the bichromate mixture must be returned to the vessel it was made in The carbon block can also be stood on end upon blotting paper or in a wide-mouthed pickle bottle. The sulphuric acid mixture can be allowed to remain in the wooden battery cells. For intermittent use such a battery will work well for months and meet every requirement for small work, either in the workshop or laboratory. No amount of hard use will injure it, if well put together as described. No acid solutions will affect it, although the liquid may be left in the cells year in and year out.

\title{
SAFE GASOLINE TANKS
}

BY DR. F. W. BREMER.
As gasoline explocions are due to a mixture of gasoline vapor with air (accidentally ignited, of course), I think the air in a gasoline tank could well be replaced either by water or a non-oxidizing gas such as carbon dioxide, after the manner here illustrated.

In the first two designs, water is used. In Fig. 1 the weight of the water forces the gasoline out of the lower tank through the stopcock $B$. The valve $C$ is so constructed that it floats when the water reaches it, closes the opening, and thus prevents the water from flowing out. To refill the tank with gasoline, a suction pump is a suction pump is connected to the
stopcock $A$ and

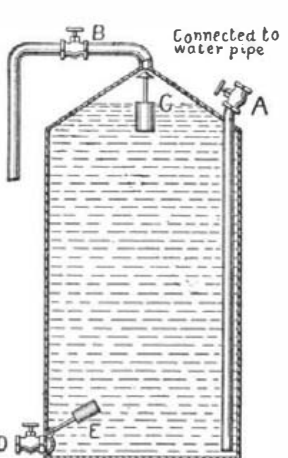

\section{tho} stopcock $A$ and
th e gasoline is th e gasoline is
siphoned into the 10 we r compartment through the stop-cock $B$. The l a t t e r prevents the gasoline from escaping.

Fig. 2 is practically the same, but to discharge the gasoline through the stop$\operatorname{cock} B$ air must

a perfect coating of pitch at these joints. Now pour the hot pitch into the cell again so as to be sure that all parts are well covered. Treat the second cell in like manner. Having the case now well put together, finish the outside by giving it two coats of shellac varnish mixed with crocus (oxide of iron). This paint will resist the acid solution used in the cells paint will resist the acid solution used in the cells
and give quite a nice finish to the work. To complete the battery procure two zinc cylinders 7 inches high, $31 / 2$ inches inside diameter, and $1 / 8$ inch thick. Also two round porous pots 3 inches diameter and 7 inches hi h Also two carbon plates or blocks 7 or 8 inches long, $1 / 2$ inch thick, and 2 inches wide. Attach two be pumped into the lowei' part to force the water into the gasoline tank above. To refill this tank with gasoline, the stopcock at $A$ is opened, letting the air out and the weight of the water then siphons the gasoline into the tank above through the valve, and stopcock $B$. In Fig. 3 a carbon dioxide tank is connected to the pipe $A$ and the pressure of the gas then forces the gasoline out through the pipe $B$.

In Fig. 4 the stopcock $A$ is connected to the water main or pipe when the pressure of the water forces the gasoline out through the stopcock $B$. The valve $C$ prevents the water from escaping into the gasoline cans through the stopcock $B$. To refill tht tank, the stopcock
$A$ is closed and stopcock $D$ is opened, and the water flowing out through the latter will draw the gasoline into the tank through stopcock $B$. The valve $E$ is adjusted to sink in gasoline and thus close the outlet, preventing escape of gasoline through the stopcock $D$.

\section{PLDG CONNECTOR.}

To make a plug connector for use in an electric light socket, all that is required is a burned out incandescent lamp and a number of feet of heavy lamp cord. Break the glass globe out of the lamp, leaving only the base. Then break away the glass tube that protects the leading-in wires, being careful not to injure them. Now untwist about a foot of the lamp cord, scrape the ends clean and slip a short length of rubber tubing over each end. Solder the ends to the leading-in wires in the lamp base and then push the rubber tubes down over the joints. Fill the socket with plaster of Paris, letting it project up above the top of the plug about an inch, so as to form an insulated top to screw the plug in by. This plug connector is suitable for small motors, portable lamps, and any other apparatus that draws only a small current. It cannot be used for large currents, as the heavy current would fuse the leading-in wires in the plug.

\section{A SIMPLE APPARATUS FOR EMPTYING CARBOYS.} BY H. H. F. CLARKE.

A very simple, effective and easily set up apparatus for emptying carboys of acid, etc., may be made in the following way from materials found in every laboratory. This will be found to be far superior to the acid pump or the old-fashioned method of tilting the carboy, catching the liquid in a jug, and then pouring it into bottles. For no fumes can escape, and this is an important factor when dealing with strong ammonia or hydrochloric acid (spirits of salts).

Say one wishes to fill with hydrochloric acid or nother liquid any number of bottles from a carboy.

Fit every one of the bottles with two-ho'ed rubber corks, and then through each hole put a piece of glass tubing bent in the form of a right angle with sides about three inches long. Connect one piece of glass tubing in one bottle to another piece in another bot tle with a small piece of rubber tubing, the free piece of this bottle with another piece in another bottle, and so on until you have all the bottles connected up in one straight line.

Connect the free tube at one end of the line with a piece of rubber tubing to a long bent glass tube passing to the bottom of the carboy.

Attach the other free tube at the other end of the row of bottles to a glass filter pump or any other suction apparatus, with a piece of thick-walled rubber tubing. Then we have the apparatus as illustrated herewith.

Turn on the water tap connected with the filter pump, and the acid will be drawn up the tube leading from the carboy and into the first bottle. As soon as this is filled, the acid will run into the second bottle, and so on until the carboy is empty or the requisite number of bottles are filled.

If one hasn't many corks, all that is necessary is to fill say three or four bottles. When these are filled, they can be disconnected and others put in their place. But it must not be forgotten to turn off the water tap, and so stop the flow of liquid before making the change.

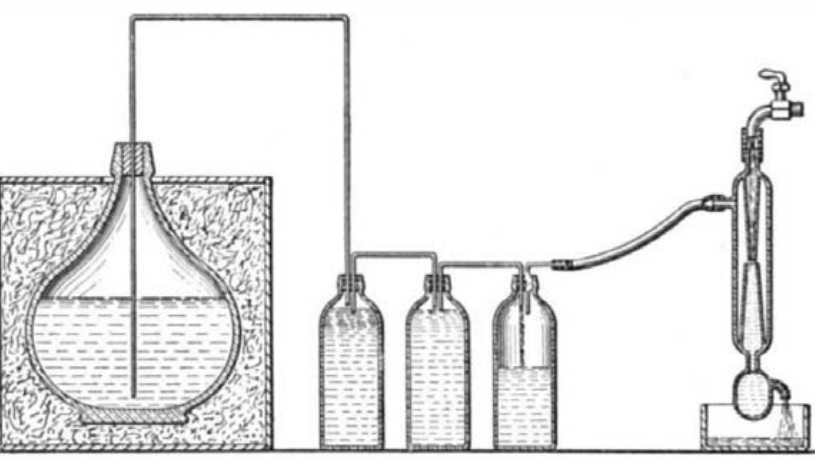

APPARATUS FOR EMPTYING CARBOYS

If the liquid in the carboy is sulphuric acid (oil of vitriol) or any other liquid that attacks rubber, the two bent tubes connecting bottle to bottle may be made in one piece, and if care is taken to push the ends of the tubes below the end of the corks, the liquid won't reach up to them, and so they will not be hurt in the slightest. In fact, no rubber connections may be made use of except from the suction pump to one end of the line of bottles, though, of course, it is more convenient to use them

A glass filter pump is the best to use, because any fumes that may perhaps come over have no corroding effect on it, as they would have on a metal one. 